\title{
U.PORTO
}

FMUP FACULDADE DE MEDICINA

UNIVERSIDADE DO PORTO

\section{Computer use in primary care and patient-physician communication}

\author{
Dilermando Jorge Resende Sobral \\ Dissertação submetida para obtenção do grau de Mestre em \\ Comunicação Clínica \\ Faculdade de Medicina da Universidade do Porto
}

Orientadora:

Professora Doutora Margarida Figueiredo-Braga

Coorientadora:

Professora Marcy Rosenbaum

Agosto 2014 
De acordo com o capítulo "Tarefas a Realizar", do Guia do Curso de Mestrado em Comunicação Clínica, a matéria da dissertação para a obtenção do grau de Mestre consta da realização de um trabalho de investigação com submissão a uma revista científica.

Na presente dissertação é apresentado o trabalho de investigação realizado sob a forma de artigo científico. 
"Se partires um dia rumo a Ítaca, faz votos de que o caminho seja longo, repleto de aventuras, repleto de saber.

Uma bela viagem deu-te Ítaca. Sem ela não te punhas a caminho. Mais do que isso não lhe cumpre dar-te." (Konstantinos Kavafis, trad. José Paulo Paes)

À minha Mãe, pelo que foi. Ao meu Pai, pelo que continua a ser. À Fátima, pelo que é. Ao João e ao Jorge, pelo que serão. 


\section{Agradecimentos / Ackowledgements}

À Professora Doutora Margarida Figueiredo-Braga, pela sua sábia presença ao longo deste caminho. Pela serenidade, pela motivação, pela confiança no percurso delineado, pela palavra certa na hora exata, pelo estímulo perspicaz e pelo dedicado esforço, que tornaram possível a concretização deste trabalho.

To Professor Marcy Rosenbaum, whose knowledge, generosity and friendship flew across the Atlantic and have been an extraordinary gift to this study.

Aos restantes docentes do Mestrado em Comunicação Clínica, pela inesquecível partilha de conhecimentos.

Às minhas colegas de mestrado, pela jovialidade, companheirismo e estimulante troca de aventuras e de experiências.

À Sara Rocha, pela assistência e apoio durante todo o mestrado.

Ao Dr. Rui Medon e à Dra. Maria José Ribas, respetivamente Diretor Executivo e Presidente do Conselho Clínico do Agrupamento de Centros de Saúde Porto Ocidental (ACESPO), pela amizade, disponibilidade e apoio na concretização deste projeto de investigação nas unidades funcionais do ‘nosso' ACES.

Aos colegas do ACESPO (médicos, enfermeiros e secretários clínicos) cujo incentivo e apoio prestado ao longo deste caminho, particularmente quando os ventos eram contrários, me permitiram manter o rumo definido.

Aos meus internos e ex-internos, pela compreensão, paciência, dedicação e fator de motivação e por terem sido a âncora nos dias mais turbulentos.

A todos os colegas e a todos os doentes que aceitaram participar neste estudo, dando sentido ao trabalho projetado.

Aos amigos, sempre presentes. 


\section{Índice}

$\begin{array}{ll}\text { Abstract } & 7\end{array}$

$\begin{array}{ll}\text { Resumo } & 9\end{array}$

1. Introduction 12

2. Methods 17

2.1. Design 17

$\begin{array}{ll}\text { 2.2. Participants } & 18\end{array}$

$\begin{array}{ll}\text { 2.2.1. Physicians } & 18\end{array}$

$\begin{array}{ll}\text { 2.2.2. Patients } & 18\end{array}$

2.3. Instruments 19

2.3.1. The Jefferson Scale of Physician Empathy (JSPE) 20

2.3.2. The Patient-Practitioner Orientation Scale (PPOS) 20

2.4. Statistical Analyses 21

3. Results 22

3.1. Sociodemographic and professional characterization 22

3.2. Physicians communication and computer skills acquisition 23

3.3. Computer use and its impact in physician-patient communication 23

3.3.1. Computer use 23

3.3.2. Impact on physician-patient communication 24

3.3.3. Time interacting with computer 25

3.4. Consultation room spatial organization and computer location 26

3.5. Empathy evaluation (JSPE) 26

3.6. Physician and patient centeredness evaluation (PPOS) 27

3.7. Correlations between PPOS and computer use and impact 27

3.8. Correlations between PPOS and empathy evaluation 29 
4. Discussion and conclusion $\quad 30$

4.1. Discussion 30

4.1.1. The impact of computer use in clinical communication 30

4.1.2. Computer use, empathy and patient-centeredness 32

4.1.3. Limitations 34

4.2. Conclusion 34

4.3. Practice implications $\quad 35$

$\begin{array}{ll}\text { Tables } & 37\end{array}$

Table 1. Sociodemographic characteristics of physician 38

Table 2. Sociodemographic characteristics of patients 39

Table 3. Acquisition of clinical communication and computer skills $\quad 40$

Table 4. Use of the computer in the consultation 41

Table 5. Impact of computer use during consultation 42

Table 6. Physical setting of the consultation room 43

Table 7. Jefferson Scale of Physicians Empathy (JSPE) 44

Table 8. Patient Practitioner Orientation Scale (PPOS) 45

Table 9. Correlation between JSPE and PPOS 46

$\begin{array}{ll}\text { Figures } & 47\end{array}$

Figure 1. Flow Diagram of the study population 48

Figure 2. Furniture arrangement in consultation room. 49

Figure 3. Location of the patient's chair. $\quad 50$

Figure 4. Location of the computer screen on the desk 51

References $\quad 52$ 


\section{ABSTRACT}

Objective: This study aimed to characterize the computer use in primary care consultations in a Portuguese Health Centers Grouping. We evaluated how physicians and patients perceive the impact of computer use in clinical communication, and how empathy and patient-centered orientation can influence this impact. A secondary aim was to provide a starting point for actions to be implemented, in order to minimize the possible negative effects of the use of computers.

Methods: The study followed a descriptive cross-sectional design and included 106 family physicians (65 specialists and 41 trainees) and 392 patients from a Health Centers Grouping in the north of Portugal. Sociodemographic and professional characterization of the participants (physicians and patients) was obtained. An original questionnaire was used to evaluate computer use and placement in the consultation room and participants' perspective of its impact. Empathy (Jefferson Scale of Physician Empathy - JSPE) and patient centered strategies (Patient-Practitioner Orientation Scale - PPOS) were assessed.

Results: Physicians reported spending $42.4 \%(\mathrm{SD}=16.4)$ of consultation time in contact with the computer. Patients perceived their physicians spending 35\% $(\mathrm{SD}=20.7)$ of consultation time interacting with the computer. Physicians perceived a negative impact of computer in patient-physician communication 
regarding the consultation length $(-0.31,1.2)$, confidentiality $(-0.38,1.1)$, maintaining eye contact $(-1.12,0.9)$, active listening to the patient $(-0.72,0.8)$, and ability to understand the patient $(-0.03,0.7)$. Patients reported a positive effect for all the items, with significantly higher scores, when compared with physicians, for the consultation length $(+0.72,1.0)$, confidentiality $(+0.83,1.0)$, maintaining eye contact $(+0.57,1.2)$, active listening to the patient $(+0.64,1.1)$, and ability to understand the patient $(+0.81,1.1)$. Physicians considered that the usual (current) computer location was significantly unfavourable to patientphysician communication.

Conclusion: Physicians perceive the impact of computer use on patientphysician communication as negative, while patients have a positive perception of computer use impact on patient-physician communication.

Practice Implications: Consultation support technologies are designed to improve quality of health care and facilitate information access. They can however represent a challenge to physicians who perceive its negative impact in patient centered orientation and empathy. Medical education programs aiming to enhance specific communication skills and to better integrate computer use in primary care settings are needed.

Keywords: Attitude to computers, clinical communication, patient centered care, physician-patient relations, primary health care. 


\section{RESUMO}

Objetivos: Este estudo pretendeu caraterizar o uso do computador em cuidados de saúde primários, num Agrupamento de Centros de Saúde do Norte do país. Foi avaliada a perceção dos médicos e dos doentes sobre o impacto da utilização do computador na comunicação clínica. Foi também analisada a influência da empatia e da abordagem centrada no doente sobre o impacto que a utilização do computador tem na comunicação médico-doente. Como objetivo secundário, pretendemos obter linhas orientadoras que possam, no futuro, minimizar os possíveis efeitos negativos do uso do computador na consulta.

Método: O estudo seguiu um desenho descritivo transversal e incluiu 106 médicos de família (65 especialistas e 41 internos) e 392 doentes, de um Agrupamento de Centros de Saúde. Foi feita a caraterização sociodemográfica e profissional dos participantes. Um questionário original permitiu avaliar a utilização do computador na consulta e a sua colocação no consultório e a perspetiva de médicos e doentes sobre o seu impacto na comunicação entre ambos. Foram também avaliadas a empatia (Jefferson Scale of Physician Empathy - JSPE) e as estratégias centradas no doente (Patient-Practitioner Orientation Scale - PPOS). 
Resultados: Os médicos relataram que a interação com o computador ocorria durante $42.4 \%(\mathrm{SD}=16.4)$ do tempo da consulta. Na opinião dos doentes, os seus médicos despendiam 35\% ( $\mathrm{SD}=20.7)$ do tempo da consulta interagindo com o computador. Os médicos caraterizaram como negativo o impacto do computador na comunicação médico-doente, no que diz respeito à duração da consulta $(-0.31,1.2)$, confidencialidade $(-0.38,1.1)$, contacto ocular $(-1.12$, $0.9)$, escuta ativa $(-0.72,0.8)$ e capacidade de compreender o doente $(-0.03$, 0.7). Os doentes referiram um efeito positivo em todos os aspetos analisados, com valores significativamente mais altos, quando comparados com os médicos, na duração da consulta $(+0.72,1.0)$, confidencialidade $(+0.83,1.0)$, contacto ocular $(+0.57,1.2)$, escuta ativa $(+0.64,1.1)$, e capacidade de compreender o doente $(+0.81,1.1)$. Os médicos consideram que a localização habitual do computador na consulta não é a mais favorável à comunicação médico-doente.

Conclusão: Os médicos caraterizam o impacto do computador na comunicação médico-doente como negativo, enquanto os doentes têm uma perceção positiva do impacto do uso do computador na comunicação médico-doente.

Repercussão na Prática Clínica: As tecnologias de apoio à consulta pretendem melhorar a qualidade dos cuidados de saúde e facilitar o acesso à informação. Podem, no entanto, representar um desafio para os médicos, que as encaram como tendo um impacto negativo na medicina centrada no doente na empatia. São necessários programas de educação médica, com o objetivo de aperfeiçoar 
capacidades específicas de comunicação clínica e de otimizar a integração do uso do computador nos cuidados de saúde primários.

Palavras-chave: Atitude frente aos computadores, comunicação clínica, cuidado centrado no paciente, cuidados primários de saúde, relações pacientemédico. 


\section{Introduction}

It is widely recognized that effective patient-physician communication, integrated in a patient-centered approach, brings greater satisfaction to patients [1] and better health outcomes, including compliance to treatment [2-5].

This communication contributes to the special relationship between the physician and the patient, taking place during the clinical encounter. In the last 30 years, the presence of a third actor in the consulting room, the computer, has potentially threatened this therapeutic relationship, as the computer has become a player with which the other two have to interact $[6,7]$.

From the first minute of the consultation, computer presence may interfere with patient-physician communication, disturbing and challenging the establishment of the necessary empathic relationship [8]. The patient may feel uncomfortable if the physician spends most of the time typing silently and does not actively listen to him, and the interview may become unnatural if controlled by prompts on the computer screen. The physician will fail to respond to nonverbal cues and the interaction will be damaged [9].

Electronic medical records are being increasingly encouraged and used in healthcare organizations around the world, and in primary care settings in particular [10-13]. Quick access to relevant information from the patient's record, greater facility in prescribing and a more efficient management of medical records are added values to primary care consultations [14-16]. Quality 
of care can also benefit from the use of the computer by means of active warning systems and follow-up planning for preventive medicine [17], chronic disease management [18] and immunization [19]. Computer use can have a positive impact on adherence to guidelines and medical error prevention, allow easy access to scientific information, and facilitate the communication between members of the health care system and with patients $[16,20]$.

On the other hand, the use of the computer has raised questions about its possible negative impact on physicians' performance and on patient care standards $[14,19]$. Concerns related to privacy and data confidentiality are shared by physicians and patients [21, 22].

Regarding the influence of computer use on the quality of patientphysician communication and relationships, several studies have been conducted since the $80 \mathrm{~s}$, in order to assess the impact of this third actor on the therapeutic relationship [19, 21, 23-32]. Albeit presenting inconsistent results, these studies seem to agree on some deleterious effects on the consultation procedure and on the patient-physician relationship. The use of the computer is reported to decrease the information disclosed by the patient and physicians responses to patients' doubts $[28,31]$, and to increase the mean time of the interview, without increasing patient satisfaction [27, 28]. In addition, computer use appears to be related to a loss of eye contact and to less psychosocial information gathering [24, 27, 28]. 
Frankel and collaborators [23] identified 4 domains in which computer use in the consultation can affect, positively or negatively, patient-physician communication: visit organization, verbal and non-verbal behaviour, computer navigation and mastery, and spatial organization of the exam room. They also observed that physicians' baseline communication skills were amplified in the presence of the computer. Physicians with good communication skills tend to better integrate the computer into the consultation [33].

In order to minimize the negative interference of the computer, some recommendations have been made regarding communication improvement and enhancement of consultation support technologies [23, 24, 34, 35].

Obviously, the most easily modifiable factor is the physical placement of the computer and monitor. Although there is no optimal placement, it is useful if the physician and patient can both see the computer monitor [23, 36, 37]. Physicians should improve their navigation and master all the potential of their computer system. Acquiring these skills will enhance efficiency and favour patient-physician communication $[23,38]$.

Specific communication skills have also been identified in order to minimize the negative interference of the computer. Booth and collaborators [24] recommended particular competencies to be included in the CalgaryCambridge Guide [39], for adequately integrating the computer in general practice consultations. These competencies are grouped under three 
subheadings: developing and maintaining rapport, involving the patient, and explanation and planning.

Ventres and collaborators suggested ten simple tips on how to incorporate the computer into a patient-centered interview [34]. These include out-of-consultation aspects (using mobile monitors, learning to type, reserving templates for documentation, separating routine data entry from patient encounters) and in-consultation aspects (start with patients' concerns, look at the patients, tell patients what you are doing, point to the screen, integrate typing around patients' needs and encourage patients' participation in building their charts). These tips have recently been modified and integrated into a teaching model of communication skills $[30,35]$.

In Portugal, computerization of the National Primary Health Care network occurred during the last decade. Little is known about how Portuguese primary care physicians use this tool and its influence on consultation procedures and on patient-physician communication. Presently, a discussion is taking place on difficulties imposed on physicians by slow computer servers and unfriendly clinical software [40]. In one study, physicians identified the information system as the main source of dissatisfaction with the Portuguese primary health care reorganization, particularly regarding aspects such as integration, speed, performance, suitability for clinical practice, and outdated hardware [41]. 
The present study was conducted in Health Centers at the North of Portugal and aimed to characterize the use of the computer in primary care consultations, collecting physicians' and patients' perspectives. The impact of computer use on patient-physician communication was studied, including on confidentiality, consultation length, ability to look at, listen to and understand the patient, and ability to collect and provide information to the patient. We investigated the influence (moderator effect) of empathy and a patient-centered orientation on this impact. As a secondary aim we intended to provide a starting point for actions to be implemented, in order to minimize the possible negative effects of the use of computers. 


\section{Methods}

\subsection{Design}

The study followed a descriptive cross-sectional design and included physicians and patients from the Health Centers Grouping of Porto Ocidental (HCGPO), in the city of Porto.

An original questionnaire was developed that evaluated sociodemographic and professional characteristics of physicians, computer use and placement during consultation, and physicians' perspective of its impact. Empathy and patient centered strategies were also assessed.

Patient's sociodemographic characteristics were evaluated. The use of the computer by the physician during the consultation and patients' perspective of its impact, patient centered strategies, and patients' perspectives regarding physicians' communicational style were studied.

Pilot studies were undertaken for both questionnaires, in order to test recruitment, study procedures and instruments.

Ethical approval for this study was obtained from North Regional Health Administration's Ethics Committee and all participants were informed about the study objectives and procedures and provided a written informed consent. 


\subsection{Participants}

\subsubsection{Physicians}

The coordinators of the 15 Family Health Units (FHU), integrating the HCGPO, received the study protocol and were invited to enter the study (Fig. 1). Thirteen FHUs (87\%) agreed to participate. One of the authors (DS) personally delivered the survey to the 142 family physicians ( 92 specialists and 50 trainees) working in the participating FHUs, during December 2013. A total of 106 family physicians ( $75 \%$ response rate) completed the survey (65 specialists and 41 trainees).

\subsubsection{Patients}

A population of 172,298 patients is registered in the HCGPO. A convenience sample of 392 patients aged 18 years or older was invited to participate in the survey. The sample size needed $(=383)$ was calculated for a 95\% confidence level and a 5\% confidence interval, using Sample Size Calculator (available at http://www.surveysystem.com/sscalc.htm). Patients were recruited from all the 13 participating FHUs. The invitation was presented by the FHU receptionists, during the months of May and June 2014, until the complete sample was collected. Participants flow and study procedures are detailed in Figure 1. 


\subsection{Instruments}

An original questionnaire was developed to evaluate sociodemographic and professional characteristics of physicians, computer use and physicians' perspective of its impact, and consultation room spatial organization.

The impact of computer use was evaluated regarding consultation length, confidentiality and ability to maintain eye contact, listen, collect information, provide information and understand the patient, using a five-point Likert-type scale, ranging from -2 (very negative) to +2 (very positive).

To evaluate consultation room spatial organization and computer location on the desk, physicians were asked to identify the option that most closely matched with their current practice, and the option they considered to be the most favourable to doctor-patient communication regarding: the arrangement of the furniture in the office (Fig. 2); the location of the patient's chair (Fig. 3); and the placement of the computer screen on the desk (Fig. 4).

Physicians' empathy was assessed using the Portuguese version [42] of the Jefferson Scale of Physician Empathy (JSPE) [43, 44]. An experimental Portuguese version of the Patient-Practitioner Orientation Scale (PPOS) [45] was used to assess how physicians value patient and practitioner centered strategies during medical interview.

Patient's sociodemographic characteristics, the use of the computer during the consultation, and their perspective of its impact were evaluated by a 
similar questionnaire. Patients' perspective on the physician's communication strategies were also evaluated, using the PPOS.

\subsubsection{The Jefferson Scale of Physician Empathy (JSPE)}

To measure physicians' empathy, the Jefferson Scale of Physician Empathy (JSPE) was used. This instrument contains 20 items, rated according to a seven-point Likert-type scale $(1=$ strongly disagree, $7=$ strongly agree $)$. It has three components: "Perspective Taking", "Compassionate Care" and "Standing in the Patient's Shoes", which is consistent with the notion of the multidimensionality of empathy [43].

The Portuguese version [42] was validated and presented good internal consistency, with a Cronbach's alpha coefficient $=0.79$, and the exploratory factor analysis defined three factors accounting for approximately $38 \%$ of the total variance, similar to those of the original version $(0.81$ e 36\%) [43].

\subsubsection{The Patient-Practitioner Orientation Scale (PPOS)}

The Patient-Practitioner Orientation Scale (PPOS) measures the roles that doctors and patients believe each should play in the course of their interaction. It is a scale with 18 items, using a six-point Likert-type scale $(1=$ strongly agree, $6=$ strongly disagree). The scale can be answered by patients and practitioners without any modification of the items and the scores are reported as means. A total mean score, ranging from "doctor-centered" to 
"patient-centered", can be calculated for the 18 items. The higher the score the more the communication can be considered patient-centered. Two sub-scale scores (for "sharing" and "caring") can also be calculated. Sharing scores reflect the extent to which the respondent believes that patients and practitioners should share power and control on a relatively equal basis, and that practitioners should share as much information with their patients as possible. Caring scores refers to the extent that respondents believe that caring about emotions and good interpersonal relations is a key aspect of the medical encounter, and that practitioners should care about the patient as a whole person rather than as a medical condition [45].

\subsection{Statistical Analyses}

Collected data were analysed using Statistical Package for the Social Sciences (SPSS, version 20.0). A descriptive analysis of the variables was carried out and the means, standard deviations, frequencies and ranges were calculated. Independent t-test or analysis of variance (ANOVA) were applied to determine and compare mean values. A $p$ value $\leq 0.05$ was considered significant. Linear and multivariate regressions were performed in order to explore significant associations between variables. 


\section{Results}

\subsection{Sociodemographic and professional characterization}

Sociodemographic and professional characteristics of physicians are listed in Table 1. From the 106 respondents (65 family physician specialists and 41 trainees), aged between 26 and 64 years old (mean 42.6), 73\% were female. Years of professional experience varied between 1 to 39 years (mean 15.3) and regarding computer experience in consultation between 1 to 20 years (mean 6.9). Studied physicians worked on average, 39.9 hours per week, and performed 18.5 consultations per day, with a mean length of 19.6 minutes.

Patients' sociodemographic characterization is presented in Table 2. Among the 392 respondents, aged between 18 and 93 years old (mean 46.9), $67 \%$ were female. The majority of participants had completed 12 years of school $(119,30.6 \%)$ or had higher education $(106,27.2 \%)$. The majority $(200$, $51.0 \%)$ were professionally active. Considering the total sample, $253(63.8 \%)$ lived with a spouse, $160(41.0 \%)$ of them with children, and $93(23.8 \%)$ without children. They were registered at the current doctor for 12.9 years (SD 10.0) and had 3.5 consultations (SD 3.1) last year, on average. 


\subsection{Physicians communication and computer skills acquisition}

Physicians reported to have acquired communication skills predominantly by clinical practice and supervision: conducting interviews themselves, observing faculty or residents and having feedback from supervisors. Trainees were found to have significantly higher undergraduate $(\mathrm{p}=0.001)$ and postgraduate $(\mathrm{p}=0.033)$ communication skills training .

Computer skills were predominantly acquired, both by trainees and specialists, from personal experience and advice from colleagues. Specialists had significantly higher scores, when compared with trainees, in theoretical training held at employer's initiative $(\mathrm{p}=0.000)$ and significantly lower scores in observing tutors $(\mathrm{p}=0.000)$. Physicians' communication and computer skills acquisition is detailed in Table 3.

\subsection{Computer use and its impact on physician-patient communication}

\subsubsection{Computer use}

While physicians reported using the computer for all suggested purposes (Table 4), it was predominantly used at the end of the consultation and before the patient enters the office, to prescribe and to record patient data. Lower scores were found in giving health information to the patient and in sharing with the patient their notes on the computer. Trainees had significantly higher 
scores $(\mathrm{p}=0.000$ and $\mathrm{p}=0.002)$ for the use of computer before $(4.8,0.5)$ and after the consultation $(4.4,1.0)$, when compared to specialists $(4.0,1.2$ and 3.6, 1.3, respectively). Trainees also showed significantly $(\mathrm{p}=0.007$ and $\mathrm{p}=0.037)$ higher scores in internet research (mean 4.3, SD 0.9) and in giving health information to the patient $(3.3,1.2)$, when compared with specialists $(3.7,1.3$ and $2.8,1.5$, respectively). Internet research $(\mathrm{r}=-0.332 ; \mathrm{p}=0.001)$, giving health information to the patient $(\mathrm{r}=-0.373 ; \mathrm{p}=0.000)$ and using computer for internal communication $(\mathrm{r}=-0.241 ; \mathrm{p}=0.013)$ had a significant negative correlation with physicians' age (data not shown).

Patients' perspectives on the use of the computer by their physicians (Table 4) presented significantly $(\mathrm{p}=0.000)$ lower scores, when compared with physicians' perspective, regarding most of the tasks performed with the computer (consult patient data, record patient data, prescribe, refer the patient to another health professional, internet research and internal communication), with the exception of "give health information to the patient" with similar results in physicians and patients.

\subsubsection{Impact on physician-patient communication}

Physicians reported a negative impact of the computer on patientphysician communication, on the duration of consultation (-0.31, SD 1.2); confidentiality $(-0.38,1.1)$; ability to look at the patient $(-1.12,0.9)$; ability to listen to the patient $(-0.72,0.8)$; and ability to understand the patient $(-0.03$, 
0.7). Trainees $(+1.29$, SD 0.7$)$ had significantly higher scores $(\mathrm{p}=0.046)$, when compared with specialists $(+0.95,0.9)$, regarding the impact of computer use on the ability to provide information to the patient.

On the other hand, patients' mean scores were positive for all items, with significantly higher scores $(\mathrm{p}=0.000)$, when compared with physicians, for the duration of consultation $(+0.72,1.0)$, confidentiality $(+0.83,1.0)$, ability to look at the patient $(+0.57,1.2)$, ability to listen to the patient $(+0.64,1.1)$, and ability to understand the patient $(+0.81,1.1)$ (Table 5). Male patients $(+1.19$, SD 0.9$)$ also had significantly higher scores $(\mathrm{p}=0.007)$, when compared with female patients $(+0.87,1.1)$, regarding the impact of computer use on the ability to provide information to the patient.

\subsubsection{Time interacting with computer}

According to their perception, physicians spent, in average, $42.4 \%$ (SD 16.4) of consultation time in contact with the computer, corresponding to 8.3 minutes in average (mean consultation length 19.6 minutes). There was no significant difference between age groups and between trainees and specialists.

Patients' perception of the time spent by their physicians interacting with the computer was, in average, 35\% (SD 20.7) (6.9 minutes) of consultation time, which is a significantly $(\mathrm{p}=0.001)$ lower score, when compared with physicians perspectives (Table 4). 


\subsection{Consultation room spatial organization and computer location}

This study evaluated three aspects of the physical setting of the consultation room: arrangement of the furniture in the office (Fig. 2), location of patient's chair (Fig. 3) and location of computer monitor on the desk (Fig. 4). For all three aspects studied, physicians reported a significant ( $\mathrm{p}=0.006$, $\mathrm{p}=0.000$ and $\mathrm{p}=0.000$ ) difference between the usual setting and the setting they considered more favourable to patient-physician communication. Results are detailed in Table 6.

\subsection{Empathy evaluation (JSPE)}

Physicians' empathy, assessed with JSPE, presented a mean total score of 119.7 (SD 10.5). Perspective Taking showed a mean score of 61.1 (SD 5.0), Compassionate Care presented a mean score of 37.7 (SD 5.10) and Standing in the Patient's Shoes a mean score of 20.9 (SD 4.0). Trainees showed a significantly higher score on Compassionate Care $(39.78,3.3)$ when compared with specialists $(36.42,5.6)$ (Table 7$)$.

Empathy total score $(\mathrm{r}=-0.354 ; \mathrm{p}=0.000)$, Compassionate Care $(\mathrm{r}=-$ 0.454; $\mathrm{p}=0.000)$ and Standing in the Patient's Shoes $(\mathrm{r}=-0.299 ; \mathrm{p}=0.002)$, showed to have a significant negative correlation with physicians' age. No 
correlations were found between JSPE scores and physicians' perceived impact of computer use on patient-physician communication.

\subsection{Physician and patient centeredness evaluation (PPOS)}

Trainees showed significantly higher scores $(\mathrm{p}=0.008, \mathrm{p}=0.015$ and $\mathrm{p}=0.029$ ) for total PPOS (mean 4.70, SD 0.4), Sharing sub-scale $(4.6,0.6)$, and Caring sub-scale $(5.24,0.5)$, when compared with specialists $(4.39,0.67 ; 3.84$, 0.72 ; and $4.94,0.80$, respectively). Physicians presented significantly higher scores $(\mathrm{p}=0.000)$ for total PPOS (mean 4.51, SD 0.6), Sharing sub-scale (3.96, 0.7) and Caring sub-scale (5.05, 0.7), when compared with patients (respectively, 3.78, 0.6; 3.37, 0.7; and 4.20, 0.7). Female patients showed significantly higher scores $(\mathrm{p}=0.031$ and $\mathrm{p}=0.025)$ for total PPOS $(3.83,0.6)$ and for Sharing sub-scale $(3.43,0.7)$, when compared with male patients (3.69, 0.6 and 3.25, 0.8, respectively). These results are detailed in Table 8 .

\subsection{Correlations between PPOS and computer use and impact}

A significant negative correlation was found in physicians, between total PPOS $(\mathrm{r}=-0.332, \mathrm{p}=0.001)$, Sharing subscale $(\mathrm{r}=-0.268, \mathrm{p}=0.006)$ and Caring subscale $(\mathrm{r}=-0.306, \mathrm{p}=0.002)$ scores and years of computer experience in consultation. 
Significant positive correlations were found between physicians' PPOS scores and computer use. Total PPOS was positively correlated with consulting patient data $(r=0.219, p=0.024)$, internet research $(r=0.194, p=0.047)$, using the computer for internal communication $(\mathrm{r}=0.280, \mathrm{p}=0.004)$, giving health information $(\mathrm{r}=0.310, \mathrm{p}=0.001)$, and using the computer after consultation $(\mathrm{r}=0.291, \mathrm{p}=0.002)$. Caring subscale was positively correlated with consulting patient data $(\mathrm{r}=0.218, \mathrm{p}=0.024)$, using the computer for internal communication $(\mathrm{r}=0.298, \mathrm{p}=0.002)$, and giving health information $(\mathrm{r}=0.248, \mathrm{p}=0.010)$ and Sharing subscale with internet research $(\mathrm{r}=0.199, \mathrm{p}=0.041)$, giving health information $(\mathrm{r}=0.289, \mathrm{p}=0.003)$ and using the computer after consultation $(\mathrm{r}=0.323, \mathrm{p}=0.001)$ (data not shown).

Regarding physicians' PPOS scores and perceived impact of computer use, significant negative correlations were detected between total PPOS and ability to listen to the patient $(\mathrm{r}=-0.197, \mathrm{p}=0.043)$ and between Caring subscale and ability to listen to the patient $(\mathrm{r}=-0.262, \mathrm{p}=0.007)$ and understand the patient $(\mathrm{r}=-0.201, \mathrm{p}=0.039)$.

A significant negative correlation was found in patients, between total PPOS and consultation length $(r=-0.128, p=0.015)$, confidentiality $(r=-0.140$, $\mathrm{p}=0.008)$ ability to look $(\mathrm{r}=-0.218, \mathrm{p}=0.000)$, listen $(\mathrm{r}=-0.232, \mathrm{p}=0.000)$ talk $(\mathrm{r}=-0.246, \mathrm{p}=0.000)$, give health information $(\mathrm{r}=-0.134, \mathrm{p}=0.010)$ and understand the patient $(\mathrm{r}=-0.232, \mathrm{p}=0.000)$, between Sharing subscale and consultation length $(r=-0.141, p=0.007)$, confidentiality $(r=-0.136, p=0.010)$, 
ability to look $(\mathrm{r}=-0.257, \mathrm{p}=0.000)$, listen $(\mathrm{r}=-0.230, \mathrm{p}=0.000)$, talk $(\mathrm{r}=-0.232$, $\mathrm{p}=0.000)$, and understand the patient $(\mathrm{r}=-0.231, \mathrm{p}=0.000)$, and between Caring subscale and listen $(\mathrm{r}=-0.124, \mathrm{p}=0.018)$, talk $(\mathrm{r}=-0.145, \mathrm{p}=0.006)$, give health information $(\mathrm{r}=-0.147, \mathrm{p}=0.005)$, and understand the patient $(\mathrm{r}=-0.124$, $\mathrm{p}=0.018$ ) (data not shown).

\subsection{Correlations between PPOS and empathy evaluation}

Physicians' PPOS total score showed a significant positive correlation with JSPE total score $(\mathrm{r}=0.475, \mathrm{p}=0.000)$, Perspective Taking $(\mathrm{r}=0.259$, $\mathrm{p}=0.007)$, Compassionate Care $(\mathrm{r}=0.433, \mathrm{p}=0.000)$ and Standing in Patient's Shoes $(\mathrm{r}=0.366, \mathrm{p}=0.000)$. Sharing subscale also showed a significant positive correlation with JSPE total score $(\mathrm{r}=0.400, \mathrm{p}=0.000)$, Compassionate Care $(\mathrm{r}=0.368, \mathrm{p}=0.000)$ and Standing in Patient's Shoes $(\mathrm{r}=0.353, \mathrm{p}=0.000)$, as well as Caring subscale with significant positive correlation with JSPE total score $(\mathrm{r}=0.423, \mathrm{p}=0.000)$, Perspective Taking $(\mathrm{r}=0.269, \mathrm{p}=0.005)$, Compassionate Care $(r=0.382, p=0.000)$ and Standing in Patient's Shoes $(r=0.281, p=0.003)$. Results are detailed in Table 9. 


\section{Discussion and conclusion}

\subsection{Discussion}

\subsubsection{The impact of computer use in clinical communication}

This study is the first one to evaluate patients' and physicians' perspectives of the impact of computer use in Portuguese primary care, particularly on physician-patient communication. Although, as stated above, several studies assessing this impact can be found in literature [19, 21, 23-32], they were performed in diverse cultural backgrounds which can shape the way patients and physicians perceive and value the impact of computers on physician-patient interaction.

One of the most interesting findings of the present study is the opposite perception of the impact of computer use in clinical communication reported by physicians and patients. Physicians considered that computer negatively influenced consultation length, confidentiality and their ability to look, listen and understand the patient. Physicians considered, on the other hand, that computer was useful in gathering and providing information during the consultations, as reported by others $[15,16]$.

Physicians' perception of negative impact was not shared by patients who considered that computer use had in general a positive impact on patientphysician communication. Patients' reaction is not surprising, since previous 
studies on patients' views about the relationship with their doctor regarding the impact of the computer stated that contact with their doctor did not differ significantly $[32,38,46-50]$. Nevertheless, concerns about confidentiality were always raised, which did not occur in this study.

We could consider that physicians in our sample regard computer as a helpful tool for specific demands but as a challenge for time management and an obstacle to actively listen and understand patients' complaints, and that patients look at the computer as a useful tool in the consultation room, which can benefit clinical communication. Physicians' generalized concerns on the impact of computer use could also be explained by the recent introduction of information system on Portuguese primary care units and by the fact that organizational and professional assignment are still ongoing [41]. One study, by Granja and collaborators, that evaluated tasks other than personal contact with patients by Portuguese family physicians, revealed that physicians spent, on average, 5.7 minutes daily with computer system malfunctions [51]. It is natural that positive expectations about information system become defrauded and physicians feel overloaded by the time spent with disturbing computer errors and troubles related to its malfunction.

Interestingly, physicians' age, gender and specialty did not modify the perceived impact of computer on patient-physician communication. Nevertheless, trainees perceived a higher beneficial impact of computer use on the ability to provide information to the patient than specialists. This finding 
may be explained by the fact that younger generations are more able to take advantage of modern technologies than older ones. This is also consistent with trainees' higher scores in using the computer for carrying out internet research and providing health information to the patient and with the negative association of these skills with physicians' age.

Physicians reported interacting with the computer for a meaningful length of time during the consultation. Although representing just patient and physician perceptions of time spent, and not an objective time count, it is surprisingly similar to results from a multi-channel video study, from Kumarapeli and collaborators [52], that registered a mean of $40,6 \%$ for the proportion of computer use in consultation. Interestingly, patients perceive this interaction as shorter, eventually corresponding to a fluid integration of computer use in the consultation.

\subsubsection{Computer use, empathy and patient-centeredness}

Patients' and physicians' perspectives of patient or doctor centeredness differed significantly. Physicians reported, in average, a doctor-centered score in total PPOS when compared to patients and their Sharing and Caring ability was also higher evaluated than by patients.

The study showed only a negative correlation between physicians' total PPOS and Caring subscale and ability to listen to the patient and between the Caring subscale and ability to understand the patient. It was expected that a 
patient-centered approach would diminish the negative impact of computer use, but we can speculate physicians that use a more patient-centered approach are more concerned with the interference of the computer and more aware of its negative effects.

From patients perspective specific patient centered strategies were negatively associated with consultation length, confidentiality, and ability to look, listen, talk, give information and understand the patient.

These results need further clarification, regarding the fact that in our study patients rated a lower patient centered approach in the consultation than physicians own evaluation.

Not surprisingly, physicians strongly associated patient centered strategies with their ability to put themselves in patient's shoes, see their perspective and be compassionate. These instruments are both useful to assess physicians' clinical communication skills.

In our sample a longer use of computer was associated with lower patient centeredness. These results could mean that computer experience in consultation as a deleterious effect in some communication skills which is consistent with the fact that trainees (who have less years of computer experience in consultation) showed significantly higher scores in the PPOS, when compared with specialists. 


\subsubsection{Limitations}

This study has several limitations, the first one being the fact that it might not be generalizable to other physician populations. It was limited to one primary care region of Portugal and the sample selection was based in willingness to participate.

Another limitation derives from the lack of objective observation of physicians' behaviour regarding computer use, since we collected self-reported evaluations. However, this was the first study to explore how Portuguese physicians perceive the inevitable presence of this third actor in the consultation, and the inclusion of patients' evaluation of this presence represents an added value to the field. Opening at the same time multiple roads for further investigation. Future research should rely on video-based or other objective evaluations of physicians' interaction with computers during consultations. Inclusion of a qualitative component in future research would permit identification of patients' and physicians' concerns regarding integration of the computer in primary care settings.

\subsection{Conclusion}

This pioneer study adds to the knowledge of how the computer is used in primary care consultations, and on the perception physicians and patients have of its influence on clinical communication. Physicians perceive a negative 
impact of computer use on patient-physician communication, while patients have the perception that computer has a positive impact in clinical communication. Physicians' empathy was not associated with the impact of computer in the clinical communication, but longer computer use along the years of experience was related with lower patient centered strategies. In conclusion, computer use does not convey a definitive negative effect in clinical communication. Present results uncovered interesting but complex relationships between specific communication strategies and computer use needing further clarification.

\subsection{Practice implications}

The enhancement of consultation support technologies should be one of the priorities of the National Health Service for primary care. Physicians' use of computer covers relevant consultation tasks and consumes a significant amount of the consultation time.

Physicians should acknowledge the fact that the computer in the consultation is not perceived as negative by the majority of patients. Nevertheless it is worthwhile to enhance physicians' competence in integrating the computer in their daily practice, in order to diminish their own negative perception. 
Medical education programs aimed at enhancing specific communication skills, in particular regarding computer use should be developed and implemented in primary care settings. 
Tables 
Table 1: Sociodemographic characteristics of physicians.

\begin{tabular}{|c|c|c|}
\hline \multicolumn{3}{|l|}{ Age } \\
\hline & Mean (SD) & $42.6(14.2)$ \\
\hline & Range & 26 to 64 \\
\hline & $<35$ & $48.6 \%$ \\
\hline & $35-44$ & $7.6 \%$ \\
\hline & $45-54$ & $5.7 \%$ \\
\hline & $55-64$ & $38.1 \%$ \\
\hline \multicolumn{3}{|l|}{ Sex } \\
\hline & Male & $29(27.4 \%)$ \\
\hline & Female & $77(72.6 \%)$ \\
\hline \multicolumn{3}{|c|}{ Career degree } \\
\hline & Trainee & $41(38.7 \%)$ \\
\hline & FP Assistant & $23(21.7 \%)$ \\
\hline & FP Graduate Assistant & $35(33.0 \%)$ \\
\hline & FP Senior Graduate Assistant & $7(6.6 \%)$ \\
\hline \multicolumn{3}{|c|}{ Years of professional experience } \\
\hline & Mean (SD) & $15.27(13.08)$ \\
\hline & Range & 1 to 39 \\
\hline \multicolumn{3}{|c|}{ Years of computer experience (in consultation) } \\
\hline & Mean (SD) & $6.86(4.67)$ \\
\hline & Range & 1 to 20 \\
\hline \multicolumn{3}{|c|}{ Working hours / week } \\
\hline & Mean (SD) & $39.88(2.64)$ \\
\hline & Range & 35 to 50 \\
\hline \multicolumn{3}{|c|}{ Consultations / day (average) } \\
\hline & Mean (SD) & $18.50(5.69)$ \\
\hline & Range & 4 to 30 \\
\hline \multicolumn{3}{|c|}{ Consultation length (minutes) } \\
\hline & Mean (SD) & $19.61(4.37)$ \\
\hline & Range & 15 to 30 \\
\hline
\end{tabular}

SD: Standard Deviation; FP: Family Physician 
Table 2: Sociodemographic characteristics of patients.

\begin{tabular}{|c|c|c|}
\hline \multicolumn{3}{|l|}{ Age } \\
\hline & Mean (SD) & $46.85(15.87)$ \\
\hline & Range & 18 to 93 \\
\hline & $<35$ & $25.3 \%$ \\
\hline & $35-44$ & $22.1 \%$ \\
\hline & $45-54$ & $17.7 \%$ \\
\hline & $55-64$ & $20.6 \%$ \\
\hline & $>64$ & $14.4 \%$ \\
\hline \multicolumn{3}{|l|}{ Sex } \\
\hline & Male & $125(32.2 \%)$ \\
\hline & Female & $263(67.8 \%)$ \\
\hline \multicolumn{3}{|c|}{ School years } \\
\hline & $<4$ years & $5(1.3 \%)$ \\
\hline & 4 years & $46(11.8 \%)$ \\
\hline & 6 years & $29(7.5 \%)$ \\
\hline & 9 years & $84(21.6 \%)$ \\
\hline & 12 years & $119(30.6 \%)$ \\
\hline & $>12$ years & $106(27.2 \%)$ \\
\hline \multicolumn{3}{|c|}{ Professional status } \\
\hline & Working & $200(51.0 \%)$ \\
\hline & Unemployed & $79(20.2 \%)$ \\
\hline & Retired & $80(20.4 \%)$ \\
\hline & Temporarily unfit to work & $14(3.6 \%)$ \\
\hline & Student & $19(4.8 \%)$ \\
\hline \multicolumn{3}{|c|}{ Family status } \\
\hline & Living alone & $54(13.8 \%)$ \\
\hline & Couple without children & $93(23.8 \%)$ \\
\hline & Couple with children & $160(41.0 \%)$ \\
\hline & Other situation & $83(21.3 \%)$ \\
\hline \multicolumn{3}{|c|}{ Years with current doctor } \\
\hline & Mean (SD) & $12.89(9.98)$ \\
\hline & Range & 1 to 40 \\
\hline \multicolumn{3}{|c|}{ Consultations last year } \\
\hline & Mean (SD) & $3.52(3.11)$ \\
\hline & Range & 0 to 20 \\
\hline
\end{tabular}

SD: Standard Deviation 
Table 3: Acquisition of clinical communication skills and computer skills.

\begin{tabular}{|c|c|c|c|c|}
\hline & $\begin{array}{c}\text { Total } \\
\mathrm{n}=106\end{array}$ & $\begin{array}{l}\text { Trainees } \\
\mathrm{n}=41\end{array}$ & $\begin{array}{l}\text { Specialists } \\
\mathrm{n}=65\end{array}$ & $p^{\mathrm{a}}$ \\
\hline \multicolumn{5}{|l|}{ Communication skills ${ }^{b}$} \\
\hline Undergraduate training & $1.69(0.93)^{\mathrm{c}}$ & $2.05(0.63)^{\mathrm{c}}$ & $1.46(1.02)^{\mathrm{c}}$ & 0.001 \\
\hline Postgraduate training - Symposium & $1.00(1.05)$ & $1.00(1.07)$ & $1.0 \quad(1.05)$ & 1.000 \\
\hline Postgraduate training - Course & $2.10(1.10)$ & $2.39(0.95)$ & $1.92(1.16)$ & 0.033 \\
\hline Postgraduate training - Workshop & $1.30(1.21)$ & $1.17(1.28)$ & $1.38(1.17)$ & 0.379 \\
\hline Postgraduate training - Master Degree & $0.28(0.77)$ & $0.41(0.89)$ & $0.20(0.67)$ & 0.161 \\
\hline $\begin{array}{l}\text { Practical training - observing faculty or } \\
\text { residents }\end{array}$ & $2.22(1.11)$ & $2.80(0.56)$ & $1.85(1.22)$ & 0.000 \\
\hline $\begin{array}{l}\text { Practical training - conducting } \\
\text { interviews themselves }\end{array}$ & $2.76(0.58)$ & $2.85(0.36$ & $2.71(0.68)$ & 0.207 \\
\hline $\begin{array}{l}\text { Practical training - discussion and } \\
\text { feedback from colleagues and } \\
\text { supervisors }\end{array}$ & $2.15(0.99)$ & $2.12(0.95)$ & $2.17(1.02)$ & 0.813 \\
\hline \multicolumn{5}{|l|}{ Computer skills ${ }^{b}$} \\
\hline $\begin{array}{l}\text { Theoretical training held at the } \\
\text { initiative of the employer }\end{array}$ & $1.43(1.01)^{\mathrm{c}}$ & $0.93(0.959)^{\mathrm{c}}$ & $1.75(0.902)^{\mathrm{c}}$ & 0.000 \\
\hline $\begin{array}{l}\text { Theoretical training held at own } \\
\text { initiative }\end{array}$ & $1.53(1.28)$ & $1.39(1.358)$ & $1.62(1.234)$ & 0.381 \\
\hline $\begin{array}{l}\text { Practical training - observing tutors / } \\
\text { mentors }\end{array}$ & $1.94(1.23)$ & $2.83(0.442)$ & $1.38(1.246)$ & 0.000 \\
\hline Practical training - personal experience & $2.87(0.48)$ & $2.98(0.156)$ & $2.80(0.592)$ & 0.066 \\
\hline $\begin{array}{l}\text { Practical training - feedback from } \\
\text { colleagues }\end{array}$ & $2.67(0.56)$ & $2.78(0.419)$ & $2.60(0.632)$ & 0.109 \\
\hline
\end{tabular}

a Independent-Samples T Test, 95\% Confidence Interval.

${ }^{\mathrm{b}}$ Scores ranging from 0 (not applicable) to 3 (contributed a lot).

${ }^{\mathrm{c}}$ Mean (Standard Deviation). 
Table 4: Use of the computer in the consultation.

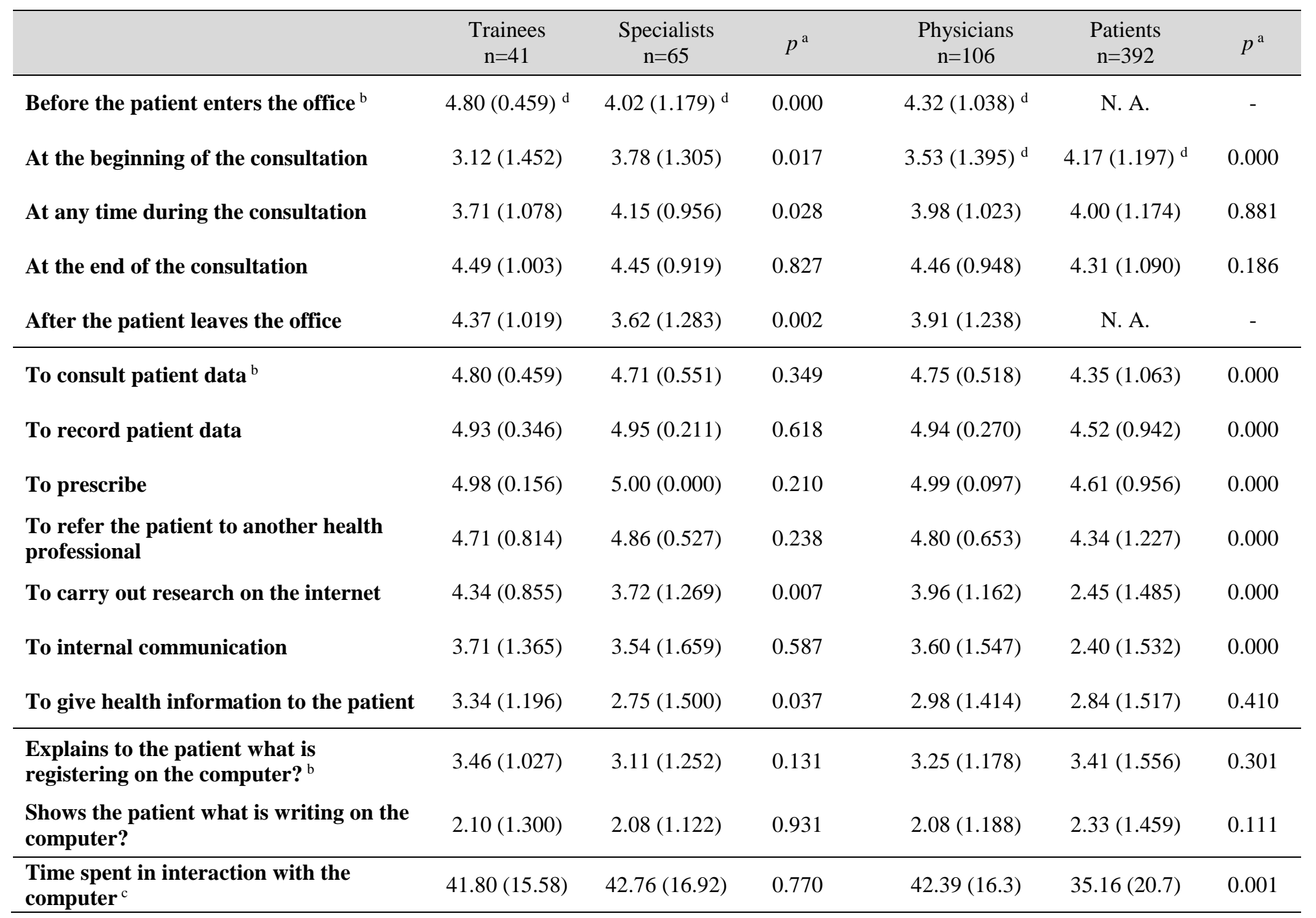

${ }^{\mathrm{a}}$ Independent-Samples T Test, $95 \%$ Confidence Interval. ${ }^{\mathrm{b}}$ Scores ranging from 1=rarely to 5=almost always; ${ }^{\mathrm{c}}$ Minutes; ${ }^{\mathrm{d}}$ Mean (Standard Deviation). 
Table 5: Impact of computer use during consultation.

\begin{tabular}{|c|c|c|c|}
\hline & $\begin{array}{l}\text { Physicians } \\
\mathrm{n}=106\end{array}$ & $\begin{array}{c}\text { Patients } \\
\mathrm{n}=392\end{array}$ & $p^{\text {a }}$ \\
\hline On duration of the consultation ${ }^{b}$ & $-0.31(1.174)^{\mathrm{c}}$ & $+0.72(1.039)^{\mathrm{c}}$ & 0.000 \\
\hline On confidentiality & $-0.38(1.060)$ & $+0.83(0.984)$ & 0.000 \\
\hline On ability to look at the patient & $-1.12(0.902)$ & $+0.57(1.222)$ & 0.000 \\
\hline On ability to listen to the patient & $-0.72(0.837)$ & $+0.64(1.107)$ & 0.000 \\
\hline $\begin{array}{l}\text { On ability to talk to the patient and } \\
\text { collect information }\end{array}$ & $+0.92(1.079)$ & $+0.70(1.124)$ & 0.085 \\
\hline $\begin{array}{l}\text { On ability to provide information to the } \\
\text { patient }\end{array}$ & $+1.08(0.852)$ & $+0.98(1.017)$ & 0.338 \\
\hline On ability to understand the patient & $-0.03(0.736)$ & $+0.81(1.068)$ & 0.000 \\
\hline
\end{tabular}

${ }^{a}$ Independent-Samples T Test, 95\% Confidence Interval.

${ }^{\mathrm{b}}$ Scores ranging from $-2=$ very negative impact to $+2=$ very positive impact.

${ }^{\mathrm{c}}$ Mean (Standard Deviation). 
Table 6: Physical setting of the consultation room.

\begin{tabular}{lllllll|}
\hline $\begin{array}{l}\text { Arrangement of the furniture in the office } \\
\text { Usual arrangement }{ }^{\mathrm{b}}\end{array}$ & $13(12.5 \%)$ & $44(42.3 \%)$ & $31(29.8 \%)$ & $16(15.4 \%)$ & \\
$\begin{array}{l}\text { The more favourable to patient-physician } \\
\text { communication }\end{array}$ & $33(32.0 \%)$ & $11(10.7 \%)$ & $16(15.5 \%)$ & $43(41.7 \%)$ & 0.006 \\
\hline
\end{tabular}

\begin{tabular}{|c|c|c|c|c|}
\hline Location of patient's chair & $\begin{array}{c}8 \\
0 \\
0\end{array}$ & $\square^{\circ}$ & a o o & $p^{\text {a }}$ \\
\hline Usual location & $\begin{array}{c}79 \\
(76.0 \%)\end{array}$ & $\begin{array}{c}24 \\
(23.0 \%)\end{array}$ & $\begin{array}{c}1 \\
(1.0 \%)\end{array}$ & \multirow{2}{*}{0.000} \\
\hline $\begin{array}{l}\text { The more favourable to patient-physician } \\
\text { communication }\end{array}$ & $\begin{array}{c}27 \\
(26.0 \%)\end{array}$ & $\begin{array}{c}75 \\
(72.1 \%)\end{array}$ & $\begin{array}{c}2 \\
(1.9 \%)\end{array}$ & \\
\hline
\end{tabular}

\begin{tabular}{|c|c|c|c|c|c|c|c|}
\hline \multirow{2}{*}{ Computer location on the desk } & & & & & 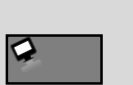 & 8 & \multirow{2}{*}{$p^{\text {a }}$} \\
\hline & 0 & 9 & 0 & $\bar{g}$ & $\infty$ & 80 & \\
\hline Usual location & $\begin{array}{c}32 \\
(31.1 \%)\end{array}$ & $\begin{array}{c}15 \\
(14.6 \%)\end{array}$ & $\begin{array}{c}40 \\
(38.8 \%)\end{array}$ & $\begin{array}{c}9 \\
(8.7 \%)\end{array}$ & $\begin{array}{c}2 \\
(1.9 \%)\end{array}$ & $\begin{array}{c}5 \\
(4.9 \%)\end{array}$ & \multirow{2}{*}{0.000} \\
\hline $\begin{array}{l}\text { The more favourable to patient- } \\
\text { physician communication }\end{array}$ & $\begin{array}{c}21 \\
(19.8 \%)\end{array}$ & $\begin{array}{c}8 \\
(7.5 \%)\end{array}$ & $\begin{array}{c}45 \\
(42.2 \%)\end{array}$ & $\begin{array}{c}26 \\
(24.5 \%)\end{array}$ & $\begin{array}{c}1 \\
(0.9 \%)\end{array}$ & $\begin{array}{c}5 \\
(4.7 \%)\end{array}$ & \\
\hline
\end{tabular}

${ }^{a}$ Chi-square test. ${ }^{b} \mathrm{n}(\%)$. 
Table 7: Jefferson Scale of Physicians Empathy (JSPE).

\begin{tabular}{lcccc}
\hline & $\begin{array}{c}\text { Total } \\
\mathrm{n}=106\end{array}$ & $\begin{array}{c}\text { Trainees } \\
\mathrm{n}=41\end{array}$ & $\begin{array}{c}\text { Specialists } \\
\mathrm{n}=65\end{array}$ & $p^{\mathrm{a}}$ \\
\hline Perspective Taking & $61.10(5.071)^{\mathrm{b}}$ & $60.80(4.556)^{\mathrm{b}}$ & $61.29(5.396)^{\mathrm{b}}$ & 0.632 \\
Compassionate Care & $37.72(5.102)$ & $39.78(3.305)$ & $36.42(5.607)$ & 0.001 \\
Standing in Patients' Shoes & $20.88(3.963)$ & $21.44(3.302)$ & $20.52(4.316)$ & 0.248 \\
Total Empathy & $119.70(10.467)$ & $122.02(7.545)$ & $118.23(11.770)$ & 0.069
\end{tabular}

Total score of JSPE has a maximum of 140.

a Independent-Samples T Test, 95\% Confidence Interval.

${ }^{\mathrm{b}}$ Mean (Standard Deviation). 
Table 8: Patient Practitioner Orientation Scale (PPOS).

\begin{tabular}{|c|c|c|c|c|c|c|c|}
\hline & $\begin{array}{c}\text { Trainees } \\
(n=41)\end{array}$ & $\begin{array}{l}\text { Specialists } \\
\quad(n=65)\end{array}$ & $\begin{array}{l}\text { Physicians } \\
(\mathrm{n}=106)\end{array}$ & $\begin{array}{l}\text { Patients } \\
(n=392)\end{array}$ & $\begin{array}{l}\text { Male Patients } \\
\qquad(\mathrm{n}=121)\end{array}$ & $\begin{array}{l}\text { Female Patients } \\
\quad(\mathrm{n}=252)\end{array}$ & $p^{\mathrm{a}}$ \\
\hline \multirow{3}{*}{ PPOS Total } & $4.70(0.390)^{b}$ & $4.39(0.670)^{b}$ & - & - & - & - & 0.008 \\
\hline & - & - & $4.51(0.596)^{b}$ & $3.78(0.591)^{b}$ & - & - & 0.000 \\
\hline & - & - & - & - & $3.69(0.604)^{b}$ & $3.83(0.577)^{b}$ & 0.031 \\
\hline \multirow{3}{*}{$\begin{array}{l}\text { PPOS } \\
\text { Sharing }\end{array}$} & $4.16(0.556)$ & $3.84(0.719)$ & - & - & - & - & 0.015 \\
\hline & - & - & $3.96(0.677)$ & $3.37(0.717)$ & - & - & 0.000 \\
\hline & - & - & - & - & $3.25(0.777)$ & $3.43(0.679)$ & 0.025 \\
\hline \multirow{3}{*}{$\begin{array}{l}\text { PPOS } \\
\text { Caring }\end{array}$} & $5.24(0.453)$ & $4.94(0.799)$ & - & - & - & - & 0.029 \\
\hline & - & - & $5.05(0.699)$ & $4.20(0.727)$ & - & - & 0.000 \\
\hline & - & - & - & - & $4.16(0.772)$ & $4.23(0.703)$ & 0.378 \\
\hline
\end{tabular}

a Independent-Samples T Test, 95\% Confidence Interval.

${ }^{\mathrm{b}}$ Mean (Standard Deviation). 
Table 9: Correlation between the Jefferson Scale of Physician's Empathy (JSPE) and the Patient-Practitioner Orientation Scale (PPOS).

\begin{tabular}{|c|c|c|c|c|c|c|c|}
\hline & \multicolumn{4}{|c|}{ JSPE } & \multicolumn{3}{|c|}{ PPOS } \\
\hline & $\begin{array}{c}\text { Perspective } \\
\text { Taking }\end{array}$ & $\begin{array}{c}\text { Compassionate } \\
\text { Care }\end{array}$ & $\begin{array}{c}\text { Standing in } \\
\text { Patient's Shoes }\end{array}$ & Total Empathy & Total PPOS & Sharing PPOS & Caring PPOS \\
\hline JSPE & & & & & & & \\
\hline Perspective Taking & 1 & & & & & & \\
\hline Standing in Patient's Shoes & $\begin{array}{l}0.225 \\
0.020\end{array}$ & $\begin{array}{l}0.598 \\
0.000\end{array}$ & 1 & & & & \\
\hline Total Empathy & $\begin{array}{l}0.653 \\
0.000\end{array}$ & $\begin{array}{l}0.797 \\
0.000\end{array}$ & $\begin{array}{l}0.779 \\
0.000\end{array}$ & 1 & & & \\
\hline PPOS & & & & & & & \\
\hline Total PPOS & $\begin{array}{l}0.259 \\
0.007\end{array}$ & $\begin{array}{c}0.43 \\
0.000\end{array}$ & $\begin{array}{l}0.366 \\
0.000\end{array}$ & $\begin{array}{l}0.475 \\
0.000\end{array}$ & 1 & & \\
\hline Sharing PPOS & $\begin{array}{l}0.178 \\
0.068\end{array}$ & $\begin{array}{l}0.368 \\
0.000\end{array}$ & $\begin{array}{l}0.353 \\
0.000\end{array}$ & $\begin{array}{l}0.400 \\
0.000\end{array}$ & $\begin{array}{l}0.862 \\
0.000\end{array}$ & 1 & \\
\hline Caring PPOS & $\begin{array}{l}0.269 \\
0.005\end{array}$ & $\begin{array}{l}0.382 \\
0.000\end{array}$ & 0.281 & 0.423 & 0.871 & $\begin{array}{l}0.501 \\
0.000\end{array}$ & 1 \\
\hline
\end{tabular}

${ }^{\mathrm{a}}$ Pearson correlation; ${ }^{\mathrm{b}} \mathrm{p}$ (two-tailed) 
Figures 
Figure 1 - Flow Diagram of the study population and data collection procedures.

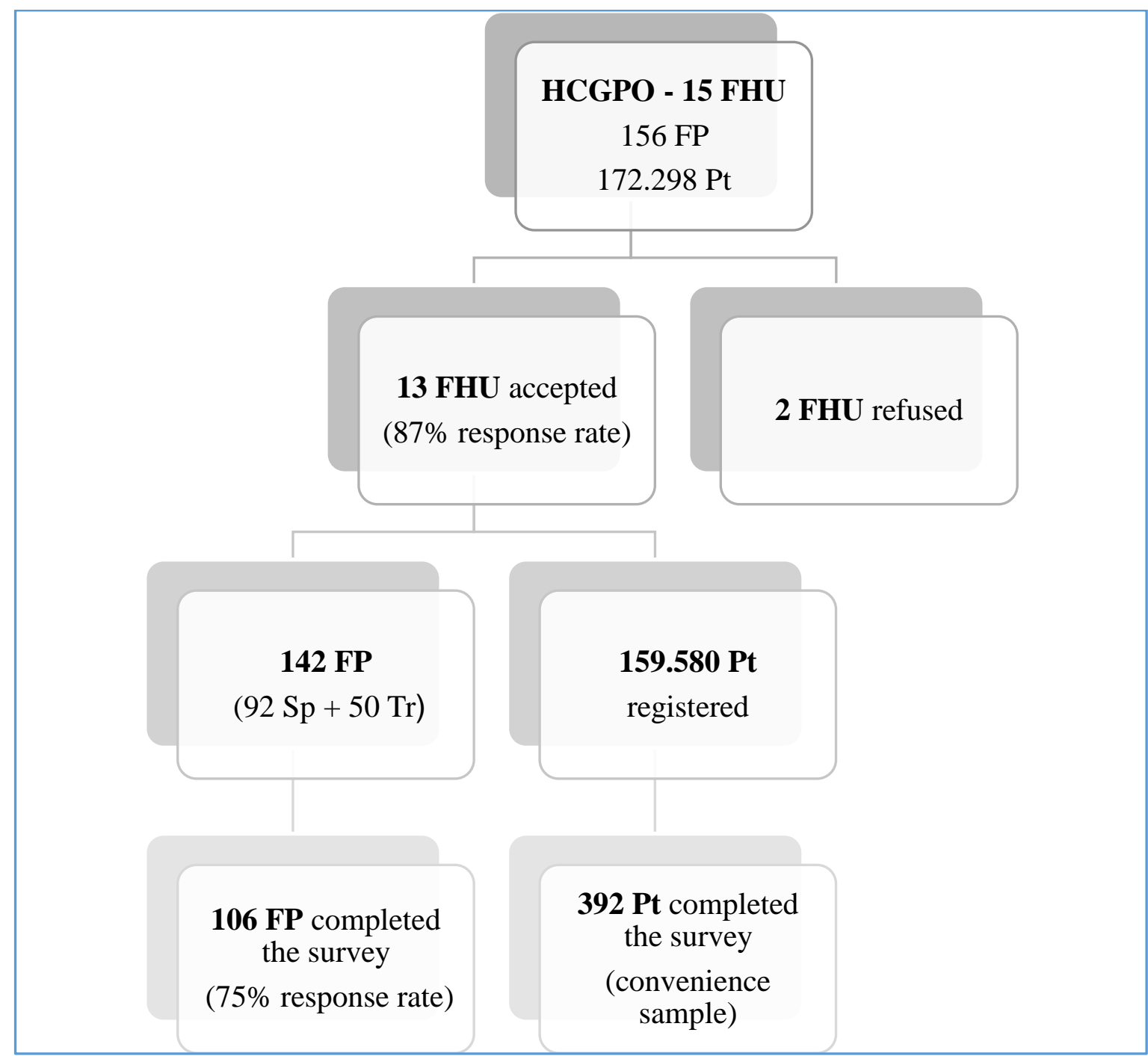

HCGPO: Health Centers Grouping of Porto Ocidental; FHU: Family Health Unit; FP: Family Physician; Sp: Specialist; Tr: Trainee; Pt: Patient 
Fig. 2: Furniture arrangement in consultation room.

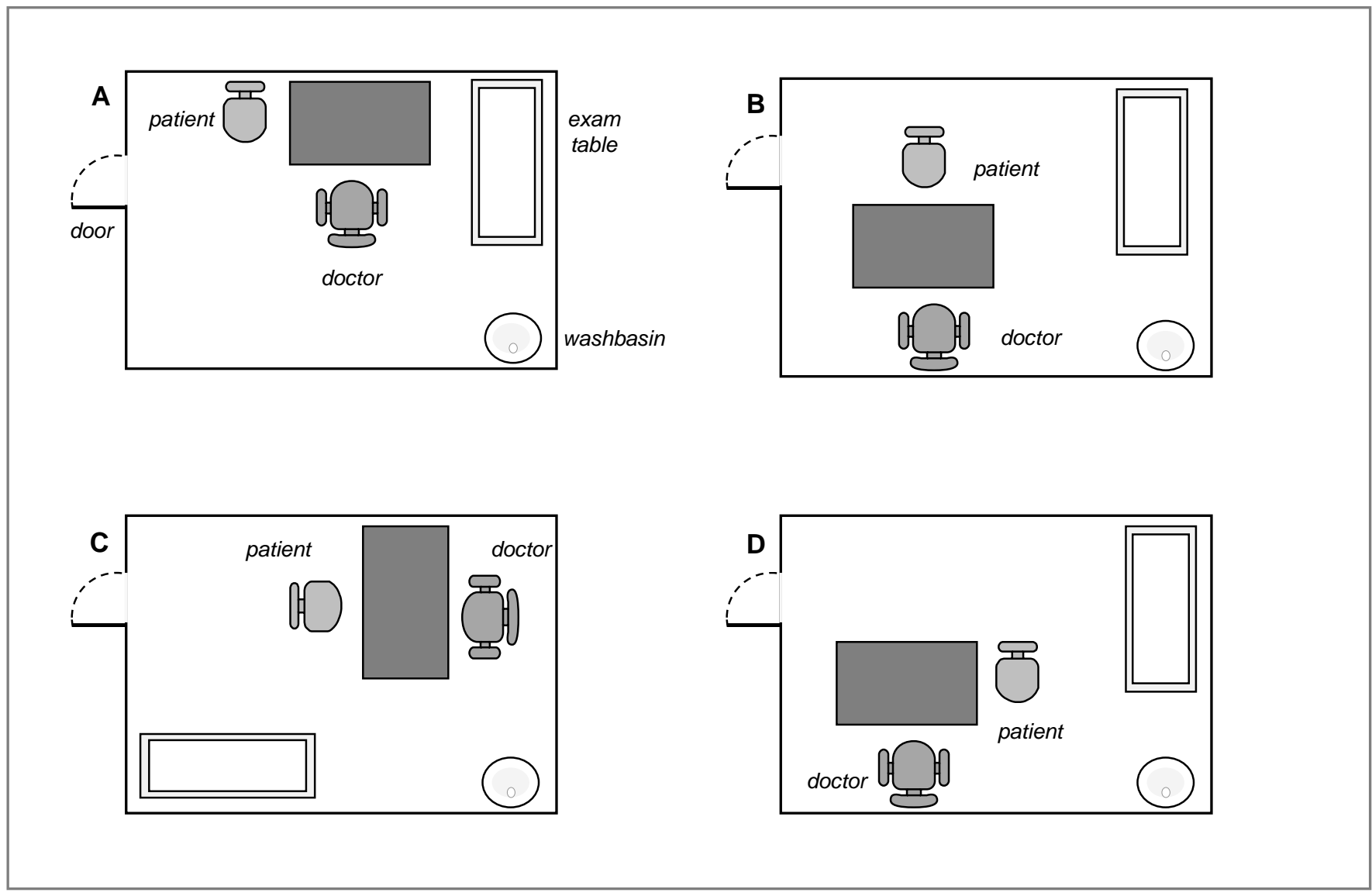


Fig. 3: Location of the patient's chair.

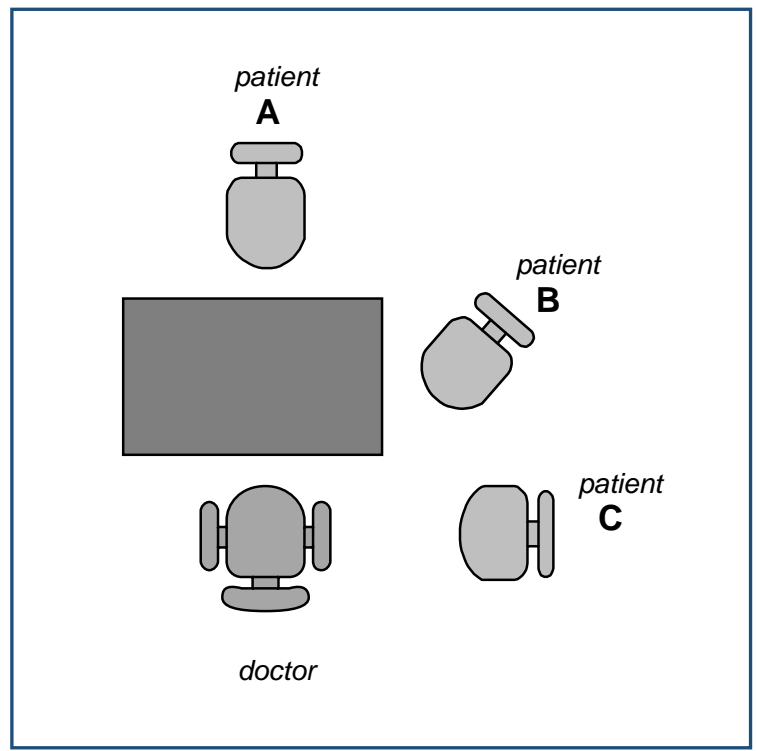


Fig. 4: Location of the computer screen on the desk.

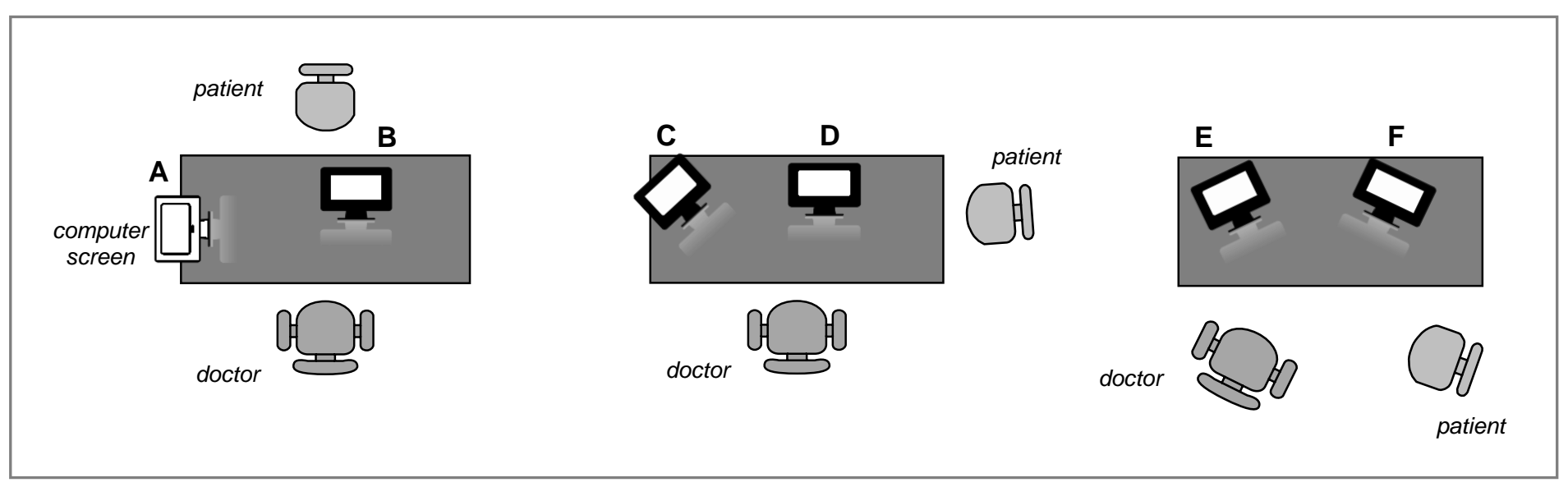




\section{References}

1. Stewart M, Meredith L, Brown JB, Galajda J. The influence of older patient-physician communication on health and health-related outcomes. Clin Geriatr Med. 2000;16(1):25-36.

2. Stewart MA. Effective physician-patient communication and health outcomes: a review. CMAJ. 1995;152(9):1423-33.

3. Stewart M, Brown JB DA, McWhinney IR, Oates J, Weston WW, Jordan J. The impact of patient-centered care on outcomes. J Fam Pract. 2000;49(9):796-804.

4. Kaplan SH, Greenfield S, Ware JE Jr. Assessing the effects of physicianpatient interactions on the outcomes of chronic disease. Med Care. 1989;27(3 Suppl):S110-27.

5. Greenfield S, Kaplan S, Ware JE Jr. Expanding patient involvement in care. Effects on patient outcomes. Ann Intern Med. 1985;102(4):520-8.

6. Pearce C, Dwan K, Arnold M, Phillips C, Trumble S. Doctor, patient and computer - a framework for the new consultation. Int $\mathrm{J}$ Med Inform. 2009;78(1):32-8.

7. Pearce C, Arnold M, Phillips C, Trumble S, Dwan K. The patient and the computer in the primary care consultation. J Am Med Inform Assoc. $2011 ; 18: 138-42$.

8. Pearce C, Trumble S, Arnold M, Dwan K, Phillips C. Computers in the new consultation: within the first minute. Fam Pract. 2008;25:202-8.

9. Ventres W. How Do EHRs Affect the Physician-Patient Relationship. Am Fam Physician. 2007;75(9):1385-90.

10. Schoen C, Osborn R, Huynh PT, Doty M, Peugh J, Zapert K. On the front lines of care: primary care doctors' office systems, experiences, and views in seven countries. Health Affairs. 2006;25(6):w555-71.

11. Protti D, Johansen I, Perez-Torres F. Comparing the application of Health Information Technology in primary care in Denmark and Andalucia, Spain. Int J Med Inform. 2009;78(4):270-83.

12. Protti D. A Comparison of How Canada, England, and Denmark are Managing their Electronic Health Record Journeys. In: Rodrigues J, editor. 
Health Information Systems: Concepts, Methodologies, Tools, and Applications: IGI Global; 2009. p. 402-27.

13. Balicer RD, Shadmi E, Lieberman N, Greenberg-Dotan S, Goldfracht M, Jana L, et al. Reducing health disparities: strategy planning and implementation in Israel's largest health care organization. Health Serv Res. 2011;46(4):128199.

14. Ellis NT, May CR. Computers and the general practice consultation. . Health Informatics Journal 1999;5(3):124-7.

15. Tai SS, Donegan C, Nazareth I. Computers in general practice and the consultation: the health professional's view. Health Informatics Journal. 2000;6(1):27-31.

16. Hersh WR. Medical informatics: improving health care through information. JAMA. 2002;288:1955-8.

17. Martins C. Preventive Services in Family Medicine. [PhD Thesis]. In press 2014.

18. Delaney BD, Fitzmaurice DA, Riaz A, Richard Hobbs FD. Can computerised decision support systems deliver improved quality in primary care? BMJ. 1999;319:1281.

19. Mitchell E, Sullivan F. A descriptive feast but an evaluative famine: systematic review of published articles on primary care computing during 1980-97. BMJ 2001;322:279-82.

20. Chaudhry B, Wang J, Wu S, Maglione M, Mojica W, Roth E, et al. Systematic review: impact of health information technology on quality, efficiency, and costs of medical care. Ann Intern Med. 2006;144(10):742-52.

21. Noordman J, Verhaak P, Beljoow I, Dulmen S. Consulting room computers and their effect on general practitioner-patient communication. Fam Pract 2010. 2010;27:644-51.

22. Garcia-Sanchez R. The patient's perspective of computerised records: a questionnaire survey in primary care. Informatics in Primary Care. 2008;16:939.

23. Frankel R, Alfschuler A, George S, Kinsman J, Jimison H, Robertson $\mathrm{NR}$, et al. Effects of Exam-Room Computing in Clinician-Patient Communication. J Gen Intern Med. 2005;20:677-82. 
24. Booth N, Robinson P, Kohannejad J. Identification of high-quality consultation practice in primary care: the effects of computer use on doctorpatient rapport. Informatics in Primary Care. 2004;12:75-83.

25. Greatbatch D, Heath C, Campion P, Luff P. How do desktop computers affect the doctor-patient interaction? Fam Pract. 1995;12(1):32-6.

26. Hsu J HJ, Fung V, Robertson N, Jimison H, Frankel R. . Health Information Technology and Physician-Patient Interactions: Impact of Computers on Communication during Outpatient Primary Care Visits. . Journal of the American Medical Informatics Association. 2005;12:474-80.

27. Makoul G, Curry RH, Tang PC. The Use of Electronic Medical Records: Communication Patterns in Outpatient Encounters. J Am Med Inform Assoc. 2001;8:610-5.

28. Margalit RS, Roter D, Dunevant MA LS, Reis S. Electronic medical record use and physician-patient communication: an observational study of Israeli primary care encounters. . Patient Educ Couns. 2006;61:134-41.

29. Nagy VT, Kanter MH. Implementing the Electronic Medical Record in the Exam Room: The Effect on Physician-Patient Communication and Patient Satisfaction. The Permanente Journal. 2007;11(2):21-4.

30. Shachak A, Reis S. The impact of electronic medical records on patientdoctor communication during consultation: a narrative literature review. Journal of Evaluation in Clinical Practice. 2009;15:641-9.

31. Miettola J, Mantyselka P, Vaskilampi T. Doctor-patient interaction in Finnish primary health care as perceived by first year medical students. BMC Medical Education. 2005;5(1):34.

32. Rethans J-J, Höppener P, Wolfs G, Diederiks J. Do personal computers make doctors less personal? Br Med J. 1988;296(6634):1446-8.

33. Ventres WB, Frankel RM. Patient-centered Care and Electronic Health Records: It's Still About the Relationship. Fam Med. 2010;42(5):364-6.

34. Ventres W, Kooienga S, Marlin R. EHR's in the Exam Room: Tips on Patient-Centered Care. Fam Pract Manag. 2006;13(3):45-7.

35. Duke P, Frankel RM, Reis S. How to Integrate the Electronic Health Record and Patient-Centered Communication Into the Medical Visit: A SkillsBased Approach. Teaching and Learning in Medicine. 2013;25(4):358-65. 
36. Almquist JR, Kelly C, Bromberg J, Bryant SC, Christianson TH, Montori VM. Consultation Room Design and the Clinical Encounter: The Space and Interaction Randomized Trial. Health Environments Research \& Design Journal. 2009;3(1):41-78.

37. Pearce C, Walker H, O'Shea C. A visual study of computers on doctors' desks. Informatics in Primary Care ;16:. 2008;16:111-7.

38. Garrison GM, Bernard ME, Rasmussen NH. 21st-Century Health Care: The Effect of Computer Use by Physicians on Patient Satisfaction at a Family Medicine Clinic. Family Medicine. 2002;34(5):362-8.

39. Kurtz S, Silverman J, Benson J, Draper J. Marrying content and process in clinical method teaching: enhancing the Calgary-Cambridge guides. Acad Med. 2003;78(8):802-9.

40. Yaphe J. Computers and doctor-patient communication. Rev Port Med Geral Fam. 2013;29:148-9.

41. Biscaia AR, Pereira A. O momento atual da reforma dos cuidados de saúde primários em Portugal. USF-AN; 2014 [7.August.2014]; Available from: https://app.box.com/s/dah80rfas907p634wcqw.

42. Salgueira AP, T TF, Aguiar P, Costa MJ. Jefferson scale of physician lifelong learning: translation and adaptation for the portuguese medical population. Acta Med Port [Internet]. 2009; 22(3):[247-56 pp.].

43. Hojat M. The Jefferson Scale of Physician Empathy. In: Hojat M, editor. Empathy in Patient Care: Springer; 2007. p. 87-115.

44. Hojat M, Mangione S, Nasca TJ, Cohen MJM, Gonnella JS, Erdmann JB, et al. The Jefferson Scale of Physician Empathy: Development and Preliminary Psychometric Data. Educational and Psychological Measurement. 2001;61:349-65.

45. Krupat E, Rosenkranz SL, Yeager CM, Barnard K, Putnam SM, Inui TS. The practice orientations of physicians and patients: the effect of doctor-patient congruence on satisfaction. Patient Educ Couns. 2000;39:49-59.

46. Legler JD, Oates R. Patients' reactions to physician use of a computerized medical record system during clinical encounters. J Fam Pract. 1993;37(3):2414.

47. Sandúa Sada JM, Sangrós González FJ, Merino Muñoz F, Fernández Rodríguez L. Altera el ordenador personal la satisfacción del paciente? . Aten Primaria. 1998;22(6):400. 
48. Buscató CR, Yuste NE, Toirán AS, Díaz SB, Font J. Opinión de profesionales y pacientes sobre la introducción de la informática en la consulta. Aten Primaria. 2005;36(4):194-7.

49. Callen J, Bevis M, McIntosh J. Patients' perceptions of general practitioners using computers during the patient-doctor consultation. Health Information Management 2005. 2005;34(1):8-12.

50. Solomon GL, Dechter M. Are patients pleased with computer use in the examination room? J Fam Pract. 1995;41(3):241-4.

51. Granja M, Ponte C, Cavadas LF. What keeps family physicians busy in Portugal? A multicentre observational study of work other than direct patient contacts. BMJ Open 2014;4:e005026 [Internet]. August 6, 2014.

52. Kumarapeli $\mathrm{P}$, de Lusignan $\mathrm{S}$. Using the computer in the clinical consultation; setting the stage, reviewing, recording, and taking actions: multichannel video study. J Am Med Inform Assoc. 2013;20:e67-e75. 
The manuscript "Computer use in primary care and physician-patient communication" was submitted for publication to Patient Education and Counseling, official journal of EACH, the European Association for Communication in Healthcare and $\mathrm{AACH}$, the American Academy on Communication in Healthcare. 